\title{
Subjective Well-Being, Life Satisfaction and Interpersonal Relationships Associated to Socio-Demographic and Contextual Variables
}

\author{
Bibiana Ramos dos $\operatorname{Santos}^{1} \cdot$ Jorge Castellá Sarriera $^{1}$ • \\ Lívia Maria Bedin ${ }^{1}$
}

(C) Springer Science+Business Media B.V., part of Springer Nature and The International Society for Qualityof-Life Studies (ISQOLS) 2018

\begin{abstract}
This study aims associating children's satisfaction to their interpersonal relationships within their main contexts of interaction (family, friends and school) and their satisfaction regarding their subjective well-being, considering the variables age, gender, type of school (public or private) and city of living (capital or not). There were 2.280 children from 9 to 13 years old $(M=10,99 ; S D=0,996)$, being 1.341 from the capital city $(58,8 \%)$, most of them from public schools $(61 \%)$ and $55,5 \%$ of the amount were girls. The results showed there is no difference between the average satisfaction data and the interpersonal relationships by age and that children living in country towns are more satisfied with their interpersonal relationships. Children who study in private schools are more satisfied with their family relationships and school environment, while students from public schools are more satisfied with their friendships; besides girls are more satisfied with both their school relationships and friends. The subjective well-being decreased as they become older and boys showed an average subjective well-being significantly higher than girls. Considering the interactions among subjective well-being and the variables evaluated, the children who presented higher average of subjective well-being are those who live in country towns and study in public schools and the ones who live in the capital and study at in private schools.
\end{abstract}

Keywords Interpersonal relationships $\cdot$ Child well-being $\cdot$ Life satisfaction

Bibiana Ramos dos Santos

bibianarsantos@hotmail.com

1 Department of Developmental and Personality Psychology, Federal University of Rio Grande do Sul (UFRGS), Porto Alegre, Brazil 
Interpersonal relationships are part of everyday life and can make our days better and more joyful or more challenging interfering directly in one's well-being. Subjective well-being is an area of scientific interest which goes further than just a concept. It was previously studied as a response to psychology's emphasis on negative aspects (Diener et al. 1999). Currently, subjective well-being is studied within Positive Psychology, which is related to human beings' strengths and potentials (Seligman and Csikszentmihalyi 2000). Subjective well-being is composed of a cognitive self evaluation of one's own life (evaluation of satisfaction with life) and the balance between the positive and negative feelings experienced (Diener 2012). The affective part of subjective well-being presented little variation, being up to $80 \%$ of well-being stability while satisfaction with life transcends life events and mood swings, yet being influenced (Diener et al. 1999). Everyday events influence life satisfaction more than specific ones, since individuals tend to return to the satisfaction level existing before the event, whether it is a positive or negative one (Gilman and Huebner 2003).

Well-being can be understood as a one-dimensional or a multidimensional concept whose dimensions include several areas, such as family, friends, the community children live in, health, safety, among others possible. These well-being dimensions may have different settings in different contexts and for diverse groups of children. Their evaluation can be accomplished globally, evaluating life satisfaction as a whole, or based on the satisfaction with each dimension, which allows the promotion of well-being in more specific contexts (Gilman and Huebner 2003). There is no consensus in the literature about what accounts for well-being or the indicators used to evaluate it, so each author studies the variables (s)he considers its components, according to his/her theoretical perspective (Lee 2014).

Studies on well-being point that satisfaction with interpersonal relationships is the most important for the global satisfaction with life in almost all the 39 populations studied (Casas 2011), including children, and it stands out as one of the most influential factors in subjective well-being (Chaplin 2009; Fattore et al. 2009). The relationships are identified as mediators between values and the satisfaction with life (Sortheix and Lonnqvist 2015). That is why, in this study, we highlight interpersonal relationships as a source of affection, among the various existing dimensions of well-being.

According to the Ecological-Contextual theory, each person is surrounded by a network of interdependent, interconnected and dynamic environments which differ in proximity and influence, called systems (Kelly 1992). Each context provides distinct relationships with specific characteristics. The system closest to the person, where the individual lives and relates, influences his development and well-being directly is called microsystem. All the relationships are established at this level. The mesosystem is composed of the various microsystems interactions (e.g., family, school, community, and the church where children participate). The exosystem comprises environments where children do not directly participate in, but which have a certain level of influence in their lives, such as their relatives' job, their school and the children protection policy, for example. Finally, the macrosystem encompasses the set of all systems, ideologies, values, religion and sociocultural processes (Sarriera 2010). The interpersonal relationships, as well as well-being, vary according to the context they are developed in and the characteristics of the people involved, such as age and gender.

Initially children relate to parents and family and, as they grow and become independent, their relationships expand to school, neighbourhood and other environments (Strelhow et al. 2013). The family is children's first development context and, 
through its values and instructions, it influences their relationships with other people (Glick et al. 2013; Li and Fung 2014). The relationships developed and observed within the family with parents and siblings interfere in life and influence children's well-being, providing relationship models (Miller et al. 2011; Yucel and Yuan 2015), so that parents' well-being influences their children's as well (Ben-Zur 2003), in spite of having a low correlation (Bedin and Sarriera 2014).

Besides family, the school is another important context in the formation of relational bases, where children interact with people from other families (Troop-Gordon and Kopp 2011). In this microsystem, in addition to formal education, children learn to defend, to position themselves, to respect and cooperate. School performance is influenced by the support students realize from teachers, friends and family (Wilmes and Andresen 2015) while children's participation in school has the potential to improve both school environment and the relationships they establish in such context (John-Akinola and Nic-Gabhainn 2014). In the academic context well-being is associated to the classroom's climate and characteristics as well as the teacher's ability to promote good social relations and acceptance among students (Horfve-Sabel 2014). A positive and affectionate relationship with the teacher favours children to establish a bond and also to ask for teacher's help when necessary. This proximity contributes to supply the children's need to establish links with adults, while the relationship with colleagues can evolve to friendship (Cava 2011). Having friends in the classroom improves academic performance and well-being in school (Shin and Ryan 2014).

The characteristics of the school context also influence children's well-being. Public and private schools offer different opportunities, according to their physical and organizational structure and teachers as well. In Brazil, private schools tend to be more structured and thus safer, due to the constancy of rules, norms, and teachers. Besides showing less consideration for their teachers' work, public schools offer less structural conditions (Lima 2012) and by changing their principals on average every three years, they may have some organizational difficulties which somehow can dishearten students and influence their well-being (Montserrat et al. 2015).

The group of friends can be considered the third relational system. Friends are essential during childhood, supporting development as well as providing companionship and affective support. Children's friends may come from school, but also from other places, such as the community where they live, extra-class activities or even places where they spend their free time, such as parks and squares (Fletcher et al. 2013). Friendship is different from relationship with classmates and is characterized by intimacy, common values and opinions, trust, mutual help and shared time (Souza et al. 2013). These relationships can act as protective factors, reducing children's chance of being excluded or victimized by peers (Troop-Gordon and Kopp 2011), and they are their most important ones, after family and school relationships (Wilmes and Andresen 2015).

According to literature, gender influences well-being (Sarriera et al. 2014). Boys score higher on well-being than girls, influenced mainly by relationships with parents (Bradshaw et al. 2011). However when using mood as an indicator of well-being, girls are more vulnerable to interpersonal stressors than boys, with higher levels of anxiety, difficulties to concentrate and depression (Flook 2011). Girls are also more influenced by their friends' behaviour (Haynie et al. 2014) and, according to MacEvoy and Asher (2012), when they disagree with friends they feel more deeply hurt and for a longer period than boys. 
Throughout their development, children's perceptions about their lives and relationships may change. According to Casas et al. (2012), subjective well-being also changes, with a lower average score as they become older. Each age group entails new discoveries and difficulties, and some authors believe that with maturity, there is a less idealized perception of reality, which can lead to a decrease in the average wellbeing in adolescence compared to childhood (Tomyn and Cummins 2011).

Besides school, another context important to well-being and relationships is the place of living, such as neighbourhood or city. According to their configuration, they can offer different opportunities for relationships. When there are reciprocal relationships, with a network of support and mutual support among relatives living nearby or neighbours, there is an increase in well-being (Tsai and Dzorgbo 2012). In bigger cities, living with extended families tends to be uncommon due to distance and the family routine. In smaller towns, on the other hand, families tend to live together more often and the relationships with neighbours are closer and more affectionate. Moreover, the sense of safety children experience in their community affects their well-being, ratifying this importance of their relationship with the environment they live in (Lee and Yoo 2015).

Analysing the contributions of each relational context, it is possible to see that these three contexts are critical to children's development, offering unique learning and growth opportunities and influencing well-being. For this reason this study focuses on the children's satisfaction with the relationships developed in each context, as well as their satisfaction with life and subjective well-being. Although literature considers the importance of interpersonal relationships for subjective well-being, there are few studies relating both concepts (Graham and Shier 2010; Goswami 2012; Malo et al. 2012; Rafnsson et al. 2015; Strelhow et al. 2013). Aiming to contribute to the wellbeing field, the present research tries to associate children's satisfactions with their interpersonal relationships in their main interaction contexts (family, friends, and school) and their satisfaction with their subjective well-being as well, considering the variables age, gender, type of school (public or private) and city where they live (capital or country town).

\section{Method}

\section{Participants}

A total of 2280 children from 9 to 13 years old $(M=10.99, S D=0.996)$, participated in the study, being $44.5 \%$ of them boys and $55.5 \%$ girls. From the total of 1341 participating children $(58.8 \%)$ came from the capital Porto Alegre and 939 children (41.2\%) from four other country cities in the state of Rio Grande do Sul (Santa Maria, Santa Cruz, Passo Fundo, Rio Grande). Most of them, corresponding to 1390 (61\%) attended public school (Table 1). The country cities and the capital were studied due to differences in their social contexts, such as city size, population size, unemployment and violence rates, in order to investigate whether these differences in characteristics influence the interpersonal relationships of the participants and their well-being. According to Table 1, the other sociodemographic variables investigated were age (10 or 12 years), gender (female or male) and type of school attended (private or public). 
Table 1 Sociodemographic distribution of the sample

\begin{tabular}{ll}
\hline Variables & $\mathrm{N}(\%)$ \\
\hline Age & \\
10 & $1318(57.8 \%)$ \\
12 & $962(42.2 \%)$ \\
City & \\
Capital & $1341(58.8 \%)$ \\
Country Town & $939(41.2 \%)$ \\
Gender & \\
Boy & $1010(44.4 \%)$ \\
Girl & $1266(55.6 \%)$ \\
Type of school & \\
Public & $1390(61 \%)$ \\
Private & $890(39 \%)$ \\
\hline
\end{tabular}

\section{Instruments}

To measure subjective well-being, two scales are used: Student Life Satisfaction Scale and Personal Well-being Index, presented below.

Student' Life Satisfaction Scale (SLSS, Huebner 1991). The SLSS is a onedimensional scale and a brief self-response measure (Huebner and Alderman 1993), developed for children and adolescents from 8 to 18 years old, comprising seven items evaluating satisfaction with life as a whole, so that they do not target any particular domain. The participant responds to the scale based on his last weeks. Originally, there are seven items: (1.) "My life is going well," (2.) "My life is just right," (3.) "I wish I could change many things in my life," (4.) "I wish I had a different kind of life," (5.) "I have a good life, " (6.) "I have what I want in life," (7.) "My life is better than most kids' lives." In this study, the adapted version was applied using only items 1, 2, 5 and 6 of the SLSS, since not all the children answered items 3 and 7, and data preparation and screening suggest that they might not have understood item 4 due to its reverse score (Borgers et al. 2000). The response alternatives vary on a 5-point Likert scale $(0=$ strongly disagree to $4=$ strongly agree $)$. Cronbach's alpha of the four items $(1,2,5$ and 6) for the sample was 0.82 .

Personal Wellbeing Index School-Children (PWI-SC, Cummins and Lau 2005) is a multidimensional scale that assesses the individual well-being through satisfaction with different domains of life. According to the authors, it was developed to evaluate the subjective dimension of quality of life, also called subjective wellbeing. It is called personal well-being considering the individual's assessment of his own life opposed to the scale that assesses the Australian national population's well-being, developed by the same authors. The PWI-SC is directed to the school population and was developed based on the PWI-A (adults), used to measure subjective well-being, consisting of seven items representing different life dimensions and answers to the question: "How satisfied are you with" : (1.) "All the things you have," (2.) "Your health," (3.) "With the things you want to be good at," (4.) "Your relationship with people in general," (5.) "About how safe you feel," (6.) "About doing things away from home," (7.) "About what can happen to you in 
the future." In this study, we used an adaptation of the PWI-SC with simpler terms. The items are answered on an 11-point scale (varying from $0=$ totally unsatisfied to $10=$ totally satisfied ) and the average domain scores constitute a measure of subjective well-being. The alpha coefficient of the sample was 0.70 .

Interpersonal Relationship Items We used 19 items related to children's relationships with their families, friends and school. Of these, 14 items are not components of a scale, but came from the questionnaire of the International Survey of Children's Well-Being (ISCWeB 2013), six of which address family life, four of them relationships at school and four address friends. The items were measured using different response styles, ranging from 4 to 5 or 11 items. The items that measure frequency of conversations, learning or fun with family and friends, and being hurt or being left out at school come with four alternative answers $(0=n o t$ once a week to $3=$ every day), and the items that assess relationships in the family, at school and with friends and measure how much the participant agrees with the statement comes with five alternative answers $(0=$ strongly disagree to $4=$ completely agree $)$.

The other 5 items on children's relations are part of the General Domain Satisfaction Index (GDSI) developed by Casas et al. (2013). The index presents 29 items and it is composed of different well-being scales, including SLSS, PWI, Overal Life Satisfaction (OLS, unique evaluation item of life as a whole) and Brief Multidimensional Student Life Satisfaction Scale (BMSLSS- Seligson et al. 2003), the scale being modified to an 11-point scale. In addition to these well-being scales, the instrument is composed of 18 items evaluating satisfaction with specific life domains. The GDSI evaluates the well-being in eight distinct domains on an 11-point scale $(0=$ totally dissatisfied to $10=$ totally satisfied $)$. In this study, we use items related to the domains satisfaction with school (two items), satisfaction with family and home (two items), and satisfaction with interpersonal relationships (one item). Although they are also part of the instrument, no GDSI items related to PWI or SLSS to avoid data duplication. The alpha coefficient of the items of the interpersonal relationships for the ample was 0.81 . All the 19 items assessing children's relationships with their family, friends and at school are presented in Tables 2 and 3.

\section{Procedures}

The schools were selected from a list provided by Rio Grande do Sul State's Department of Education that authorizes the research with students. The principals of the schools signed the Institutional Agreement Term and the children invited to take part in the research received a Consent Form. Only the children whose parents or the person responsible for them have signed the terms participated in it. The application forms were filled out in the classroom, at a time previously scheduled with the school, during class for nearly $45 \mathrm{~min}$. Participants were told their refusal or withdrawal would not cause any problem. All ethical requirements were followed in this study.

\section{Data Analysis}

To accomplish the goal, a multivariate analysis of variance (MANOVA) was performed to analyse the level of association between satisfaction and the interpersonal 
Table 2 Items of interpersonal relationship means by age and gender

\begin{tabular}{|c|c|c|c|c|}
\hline & \multicolumn{4}{|l|}{ Mean (SD) } \\
\hline & \multicolumn{2}{|l|}{ Age } & \multicolumn{2}{|l|}{ Gender } \\
\hline & 10 years & 12 years & Girls & Boys \\
\hline \multicolumn{5}{|l|}{ Family } \\
\hline 1. My parents listen to me and take what I say into account ${ }^{\mathrm{b}}$ & $3.02(1.03)$ & $2.88(1.07)$ & $2.95(1.06)$ & $2.97(1.03)$ \\
\hline 2. We have a good time together in my family ${ }^{\mathrm{b}}$ & $3.47(0.84)$ & $3.35(0.85)$ & $3.42(0.84)$ & $3.42(0.85)$ \\
\hline 3. My parents treat me in a fair way ${ }^{\mathrm{b}}$ & $3.70(0.63)$ & $3.63(1.69)$ & $3.67(0.65)$ & $3.67(0.66)$ \\
\hline 4. How often does family: Have fun together ${ }^{\mathrm{a}}$ & $1.96(0.91)$ & $1.82(0.90)$ & $1.94(0.88)$ & $1.85(0.93)$ \\
\hline 5. How often does family: Talk together ${ }^{\mathrm{a}}$ & $2.15(0.91)$ & $2.18(0.87)$ & $2.16(0.90)$ & $2.17(0.89)$ \\
\hline 6. How often does family: Learn together ${ }^{\mathrm{a}}$ & $2.03(0.97)$ & $1.69(1.02)$ & $1.91(1.00)$ & $1.87(1.01)$ \\
\hline 7. Satisfaction with: The people you live with ${ }^{\mathrm{c}}$ & $9.29(1.67)$ & $9.19(1.64)$ & $9.25(1.66)$ & $9.24(1.65)$ \\
\hline 8. Satisfaction with: All the other people in your family ${ }^{\mathrm{c}}$ & $9.03(1.75)$ & $8.58(2.07)$ & $8.87(1.90)$ & $8.81(1.90)$ \\
\hline \multicolumn{5}{|l|}{ School } \\
\hline 9. My teachers treat me in a fair way ${ }^{\mathrm{b}}$ & $3.51(0.77)$ & $3.11(0.88)$ & $3.38(0.81)$ & $3.30(0.88)$ \\
\hline $\begin{array}{l}\text { 10. My teachers listen to me and take what I say into } \\
\text { account }^{b}\end{array}$ & $3.10(0.99)$ & $2.26(1.03)$ & $2.97(0.99)$ & $2.87(1.07)$ \\
\hline 11. How often you were hit by other kids ${ }^{1 \mathrm{a}}$ & $2.50(0.89)$ & $2.72(0.69)$ & $2.63(0.76)$ & $2.54(0.88)$ \\
\hline $\begin{array}{l}\text { 12. How often you were left out by other kids from your } \\
\text { classroom }^{1 \mathrm{a}}\end{array}$ & 2.34(1.00) & $2.45(0.92)$ & $2.33(1.00)$ & $2.45(0.93)$ \\
\hline 13. Satisfaction with: The school you go to ${ }^{\mathrm{c}}$ & $9.20(1.76)$ & $8.73(2.01)$ & $9.07(1.83)$ & $8.92(1.94)$ \\
\hline 14. Satisfaction with: Other children in your class ${ }^{c}$ & $8.31(2.23)$ & $7.96(2.20)$ & $8.12(2.23)$ & $8.22(2.21)$ \\
\hline \multicolumn{5}{|l|}{ Friends } \\
\hline 15. How often do friends: Have fun together ${ }^{\mathrm{a}}$ & $\begin{array}{l}1.90 \\
(1.06)\end{array}$ & $1.83(1.06)$ & $1.89(1.05)$ & $1.85(1.04)$ \\
\hline 16. How often do friends: Talk together ${ }^{\mathrm{a}}$ & $2.06(1.00)$ & $2.17(0.95)$ & $2.15(0.98)$ & $2.06(0.98)$ \\
\hline 17. Satisfaction with your friends ${ }^{c}$ & $9.08(1.72)$ & $8.84(1.79)$ & $9.05(1.75)$ & $8.90(0.75)$ \\
\hline 18. My friends are usually nice to $\mathrm{me}^{\mathrm{b}}$ & $3.23(0.96)$ & $3.16(0.89)$ & $3.25(0.93)$ & $3.15(0.93)$ \\
\hline 19. I have enough friends ${ }^{\mathrm{b}}$ & $3.11(1.12)$ & $2.97(1.14)$ & $3.09(1.10)$ & $3.01(1.17)$ \\
\hline \multicolumn{5}{|l|}{ SLSS4 } \\
\hline 1. My life is going well ${ }^{\mathrm{b}}$ & $3.51(0.73)$ & $3.21(0.84)$ & $3.35(0.81)$ & $3.42(0.76)$ \\
\hline 2. My life is just right ${ }^{\mathrm{b}}$ & $3.06(1.02)$ & 2.73(1.07) & $2.87(1.08)$ & $2.98(1.03)$ \\
\hline 3. I have a good life ${ }^{b}$ & $3.62(0.72)$ & $3.39(0.85)$ & $3.48(0.81)$ & $3.58(0.75)$ \\
\hline 4. I have what I want in life ${ }^{\mathrm{b}}$ & $3.12(1.04)$ & $2.84(1.02)$ & $2.94(1.06)$ & $3.08(1.00)$ \\
\hline \multicolumn{5}{|l|}{ PWI - How satisfied you are with } \\
\hline 1. All the things you have ${ }^{\mathrm{c}}$ & $9.52(1.18)$ & $9.05(1.53)$ & $9.31(1.42)$ & $9.33(1.29)$ \\
\hline 2. Your health ${ }^{\mathrm{c}}$ & $9.51(1.25)$ & $9.29(1.51)$ & $9.45(1.32)$ & $9.37(1.43)$ \\
\hline 3. The things you want to be good at $\mathrm{c}^{\mathrm{c}}$ & $9.25(1.46)$ & $8.64(1.86)$ & $8.93(1.69)$ & $9.07(1.62)$ \\
\hline 4. Your relationships with people in general $^{\mathrm{c}}$ & $8.77(1.97)$ & $8.63(1.87)$ & $8.78(1.89)$ & $8.63(1.97)$ \\
\hline 5. How safe you feel ${ }^{\mathrm{c}}$ & $8.92(1.89)$ & $8.30(2.12)$ & $8.56(2.13)$ & $8.78(1.85)$ \\
\hline 6. Doing things away from your home ${ }^{\mathrm{c}}$ & $7.99(2.67)$ & $7.94(2.48)$ & $7.96(2.58)$ & $7.98(2.60)$ \\
\hline 7. What may happen to you later in your life $\mathrm{f}^{\mathrm{c}}$ & $8.92(1.97)$ & $8.65(2.01)$ & $8.81(1.98)$ & $8.80(2.01)$ \\
\hline
\end{tabular}

\footnotetext{
${ }^{1}$ inverted items

a 4 -point scale $(0=$ Not even once a week to $3=$ every day)

${ }^{\mathrm{b}} 5$ point scale $(0=$ strongly disagree to $4=$ strongly agree $)$

c 11 -point scale $(0=$ totally dissatisfied to $11=$ totally satisfied $)$
} 
Table 3 Items of interpersonal relationship average by type of school and city

\begin{tabular}{|c|c|c|c|c|}
\hline & \multicolumn{4}{|c|}{ Means (SD) } \\
\hline & \multicolumn{2}{|c|}{ School type } & \multicolumn{2}{|l|}{ City } \\
\hline & Private & Public & Capital & $\begin{array}{l}\text { Country } \\
\text { Town }\end{array}$ \\
\hline \multicolumn{5}{|l|}{ Interpersonal relationship items } \\
\hline 1. My parents listen to me and take what I say into account ${ }^{\mathrm{b}}$ & $3.07(0.97)$ & $2.88(1.09)$ & 2.91(1.09) & $3.03(0.99)$ \\
\hline 2. We have a good time together in my family ${ }^{\mathrm{b}}$ & $3.49(0.81)$ & $3.38(0.86)$ & $3.40(0.85)$ & $3.45(0.81)$ \\
\hline 3. My parents treat me in a fair way ${ }^{\mathrm{b}}$ & $3.78(0.53)$ & $3.60(0.72)$ & $3.61(0.72)$ & $3.75(0.53)$ \\
\hline 4. How often does family: Have fun together ${ }^{\mathrm{a}}$ & $1.87(0.86)$ & $1.92(0.94)$ & $1.88(0.91)$ & $1.93(0.90)$ \\
\hline 5. How often does family: Talk together ${ }^{\mathrm{a}}$ & $2.23(0.82)$ & $2.12(0.94)$ & $2.09(0.93)$ & $2.28(0.83)$ \\
\hline 6. How often does family: Learn together ${ }^{\mathrm{a}}$ & $1.81(0.98)$ & $1.94(1.02)$ & $1.87(1.02)$ & $1.92(0.99)$ \\
\hline 7. Satisfaction with: The people you live with ${ }^{\mathrm{c}}$ & $9.43(1.34)$ & $9.13(1.82)$ & $9.18(1.75)$ & $9.35(1.49)$ \\
\hline 8. Satisfaction with: All the other people in your family ${ }^{\mathrm{c}}$ & $9.01(1.60)$ & $8.74(2.07)$ & $8.83(1.94)$ & $8.86(1.85)$ \\
\hline 9. My teachers treat me in a fair way ${ }^{\mathrm{b}}$ & $3.42(0.74)$ & $3.30(0.90)$ & $3.34(0.87)$ & $3.35(0.80)$ \\
\hline $\begin{array}{l}\text { 10. My teachers listen to me and take what I } \\
\text { say into account }{ }^{b}\end{array}$ & $3.06(0.91)$ & 2.84(1.09) & $2.84(1.07)$ & $3.04(0.96)$ \\
\hline 11. How often you were hit by other kids ${ }^{1 \mathrm{a}}$ & $2.69(0.68)$ & $2.53(0.90)$ & $2.56(0.85)$ & $2.64(0.76)$ \\
\hline $\begin{array}{l}\text { 12. How often you were left out by other kids } \\
\text { from your classroom }\end{array}$ & $2.46(0.90)$ & $2.34(1.01)$ & $2.36(1.00)$ & $2.43(0.93)$ \\
\hline 13. Satisfaction with: The school you go to ${ }^{c}$ & $9.35(1.46)$ & $8.78(2.08)$ & $8.94(1.91)$ & $9.10(1.82)$ \\
\hline 14. Satisfaction with: Other children in your class ${ }^{c}$ & $8.45(1.87)$ & $7.98(2.41)$ & $8.10(2.27)$ & $8.25(2.16)$ \\
\hline 15. How often do friends: Have fun together ${ }^{\mathrm{a}}$ & $1.83(1.03)$ & $1.90(1.05)$ & $1.84(1.91)$ & $1.91(1.00)$ \\
\hline 16. How often do friends: Talk together ${ }^{\mathrm{a}}$ & $2.08(0.98)$ & $2.12(0.98)$ & $2.07(1.02)$ & $2.15(0.92)$ \\
\hline 17. Satisfaction with your friends ${ }^{c}$ & $8.99(1.59)$ & $8.97(1.86)$ & $8.95(1.80)$ & $9.02(1.68)$ \\
\hline 18. My friends are usually nice to $\mathrm{me}^{\mathrm{b}}$ & $3.21(0.89)$ & $3.20(0.96)$ & $3.16(0.96)$ & $3.26(0.88)$ \\
\hline 19. I have enough friends ${ }^{b}$ & $3.06(1.09)$ & $3.05(1.16)$ & $3.04(1.16)$ & $3.07(1.10)$ \\
\hline \multicolumn{5}{|l|}{ SLSS4 } \\
\hline 1. My life is going well ${ }^{\mathrm{b}}$ & $3.40(0.74)$ & $3.37(0.82)$ & $3.37(0.80)$ & $3.40(0.77)$ \\
\hline 2. My life is just right ${ }^{\mathrm{b}}$ & $2.89(1.00)$ & $2.94(1.10)$ & $2.90(1.07)$ & $2.95(1.04)$ \\
\hline 3. I have a good life ${ }^{b}$ & $3.56(0.75)$ & $3.50(0.81)$ & $3.50(0.80)$ & $3.55(0.76)$ \\
\hline 4. I have what I want in life ${ }^{b}$ & $3.06(0.97)$ & $2.97(1.08)$ & $3.01(1.04)$ & $2.99(1.04)$ \\
\hline \multicolumn{5}{|l|}{ PWI - How satisfied you are with } \\
\hline 1. All the things you have $\mathrm{c}^{\mathrm{c}}$ & $9.31(1.21)$ & $9.33(1.45)$ & $9.35(1.36)$ & $9.31(1.21)$ \\
\hline 2. Your health ${ }^{\mathrm{c}}$ & $9.47(1.19)$ & $9.38(1.47)$ & $9.36(1.45)$ & $9.47(1.19)$ \\
\hline 3. The things you want to be good $a t^{c}$ & $8.90(1.55)$ & $9.05(1.73)$ & $8.96(1.73)$ & $8.90(1.55)$ \\
\hline 4. Your relationships with people in general $^{\mathrm{c}}$ & $8.82(1.59)$ & $8.64(2.11)$ & $8.62(2.08)$ & $8.82(1.59)$ \\
\hline 5. How safe you feel ${ }^{\mathrm{c}}$ & $8.74(1.80)$ & $8.61(2.13)$ & $8.57(2.10)$ & $8.74(1.81)$ \\
\hline 6. Doing things away from your home ${ }^{\mathrm{c}}$ & $8.23(2.21)$ & $7.80(2.79)$ & $7.90(2.61)$ & $8.23(2.21)$ \\
\hline 7. What may happen to you later on in life $\mathrm{e}^{\mathrm{c}}$ & $8.86(1.70)$ & $8.77(2.16)$ & $8.74(2.11)$ & $8.86(1.70)$ \\
\hline
\end{tabular}

\footnotetext{
${ }^{1}$ inverted items

a 4 -point scale $(0=$ Not even once a week to $3=$ every day)

${ }^{\mathrm{b}} 5$ point scale $(0=$ strongly disagree to $4=$ strongly agree $)$

${ }^{\mathrm{c}} 11$-point scale $(0=$ totally dissatisfied to $11=$ totally satisfied $)$
} 
relationships (family, friends and school), with the following factors: age (10 or 12 years), gender (female or male), type of school (public or private) and city of living (capital city or not). These data will also be used to analyse the relationships between the well-being and children's life satisfaction, considering the factors above mentioned.

\section{Results}

\section{Descriptive Analysis}

In Table 2, the mean and standard deviations of the 19 items of interpersonal relationships are presented, as well as the items of the well-being scales, four items from SLSS4 and seven items from PWI.

Table 3 presents the means of interpersonal relationships and well-being items, considering type of school and city where the children live.

\section{Multivariate Analysis of Variance (MANOVA)}

From previous studies, it was noticed that the items of interpersonal relationships are grouped into three factors (family, friends and school), used in the present study as dependent variables. The obtained factors were used in two Multivariate Analyses of Variance (MANOVA), as well as the scores of well-being obtained through the Principal Component Analysis (PCA) of four items from the Student Life Satisfaction Scale / SLSS (Huebner 1991) and the PCA of the seven items of the Personal Well-being Index/PWI-SC (Cummins and Lau 2005). Two MANOVAs were carried out to evaluate if there were differences between the average of children regarding gender, age, city and type of school for the variables dependent on well-being and interpersonal relationships.

In the first MANOVA, the dependent variables related to interpersonal relationships are the three factors: family, friends and school (Table 4). The independent variables or factors used were age (10 or 12), gender (girl or boy), city where the children live (capital city or not) and type of school the children attend to (private or public).

On the whole, there is a significant difference in the average for family, friends and school factors considering the variables gender, city and type of school. There were no significant differences considering the interaction among any of the four independent variables, so they

Table 4 Multivariate analysis of variance: Family, School and Friends relationship

\begin{tabular}{llllll}
\hline Effect $^{\mathrm{a}}$ & Value $^{\mathrm{b}}$ & $F$ & $d f$ & $d f$ error & Sig. \\
\hline Age & 0.998 & 1.149 & 3 & 1.750 & 0.328 \\
Gender & 0.992 & 4.525 & 3 & 1.750 & $0.004^{*}$ \\
City & 0.994 & 3.564 & 3 & 1.750 & 0.014 \\
Type of school & 0.964 & 21.846 & 3 & 1.750 & $0.001^{* *}$ \\
\hline
\end{tabular}

\footnotetext{
a dependent variables: family, friends, school

b Wilks' Lambda

$* p \leq 0.05 ; * * p \leq 0.01$
} 
are not presented in the table. Univariate analyses of variance were performed to verify in which interpersonal relationship the differences are significant (Table 5).

Regarding age, as well as in the MANOVA, it was observed that there is no significant difference between the average in the children from 10 and 12 years old interpersonal relations. Regarding housing context, it is observed that children who live in country towns have significantly higher means of relationships with their families than children from the capital city.

Regarding the type of school, it is observed that children who study in private schools have significantly higher average in family and school relations, indicating greater satisfaction with both environments. However concerning relations with friends, children who study in public school obtained a higher mean, which can be consequence of having more free time and, thus spending more time with friends when compared to children from private schools. As to gender, in the relationships developed in the school context and with friends, girls presented a higher mean, suggesting a greater appreciation of these relationships.

The second MANOVA was performed to verify if there are significant differences in the average scores of children's well-being according to age, gender, type of school and housing context (Table 6). As dependent variables, two scales that measure subjective well-being were used, PWI and SLSS.

Altogether there is a significant difference in the average of well-being factors (SLSS and PWI) for the variables age, gender, city, as well as in the interaction between the variables city and type of school. Among the other independent variables, there was no significant interaction (data left out). To verify in which well-being factor there is a significant difference between average data an univariate analyses of variance was developed, allowing a clearer view of differences (Table 7).

Table 5 Variance analysis and means: Family, Friends and School

\begin{tabular}{|c|c|c|c|c|c|c|c|c|}
\hline \multirow{2}{*}{$\begin{array}{l}\text { Independent } \\
\text { variables } \\
\text { Age }\end{array}$} & \multirow{2}{*}{$\begin{array}{l}\text { Dependent } \\
\text { variables }\end{array}$} & \multicolumn{2}{|c|}{ Factors' means (SD) } & \multirow[t]{2}{*}{ Sum of squares } & \multirow[t]{2}{*}{$d f$} & \multirow[t]{2}{*}{$d f$ error } & \multirow[t]{2}{*}{$F$} & \multirow[t]{2}{*}{ Sig. } \\
\hline & & 10 years & 12 years & & & & & \\
\hline & Family & $-0.03(0.97)$ & $0.04(1.03)$ & 3.205 & 1 & 3.205 & 3.242 & 0.072 \\
\hline & School & $0.01(0.99)$ & -0.01 & 0.229 & 1 & 0.229 & 0.237 & 0.627 \\
\hline & Friends & $0.01(0.99)$ & $-0.01(1.00)$ & 0.004 & 1 & 0.004 & 0.005 & 0.946 \\
\hline \multirow[t]{4}{*}{ City } & & Capital & Country Town & & & & & \\
\hline & Family & $-0.08(1.04)$ & $0.11(0.93)$ & 8.386 & 1 & 8.386 & 8.482 & $0.004 * *$ \\
\hline & School & $-0.05(1.03)$ & $0.07(0.95)$ & 1.060 & 1 & 1.060 & 1.095 & 0.295 \\
\hline & Friends & $-0.01(1.05)$ & $0.01(0.92)$ & 1.052 & 1 & 1.052 & 1.065 & 0.302 \\
\hline \multirow[t]{4}{*}{ Type of School } & & Public & Private & & & & & \\
\hline & Family & $-0.06(1.05)$ & $0.08(0.91)$ & 5.370 & 1 & 5.370 & 5.432 & $0.020 *$ \\
\hline & School & $-0.13(1.06)$ & $0.18(0.87)$ & 38.618 & 1 & 38.618 & 39.910 & $0.001 * *$ \\
\hline & Friends & $0.09(1.02)$ & $-0.13(0.96)$ & 18.506 & 1 & 18.506 & 18.723 & $0.001 * *$ \\
\hline \multirow[t]{4}{*}{ Gender } & & Boys & Girls & & & & & \\
\hline & Family & $-0.01(0.96)$ & $0.01(1.03)$ & 0.375 & 1 & 0.375 & 0.379 & 0.538 \\
\hline & School & $-0.04(1.04)$ & $0.03(0.96)$ & 3.911 & 1 & 3.911 & 4.042 & $0.045^{*}$ \\
\hline & Friends & $-0.08(1.01)$ & $0.07(0.98)$ & 9.217 & 1 & 9.217 & 9.325 & $0.002 * *$ \\
\hline
\end{tabular}

$*=p \leq 0.05 ; * *=p \leq 0.01$ 
Table 6 Multivariate analysis of variance: Subjective well-being

\begin{tabular}{llllll}
\hline Effect $^{\mathrm{a}}$ & Value $^{\mathrm{b}}$ & $F$ & $d f$ & $d f$ error & Sig. \\
\hline Age & 0.970 & 32.61 & 2 & 2.094 & $0.001^{*}$ \\
Gender & 0.992 & 8.23 & 2 & 2.094 & $0.001^{*}$ \\
City & 0.996 & 3.73 & 2 & 2.094 & $0.024^{* *}$ \\
Type of school & 0.999 & 1.44 & 2 & 2.094 & 0.236 \\
City * Type of school & 0.997 & 3.29 & 2 & 2.094 & $0.037^{* *}$ \\
\hline
\end{tabular}

a dependent variables: SLSS and PWI

${ }^{\mathrm{b}}$ Wilks' Lambda

$*=p \leq 0.01 ; * *=p \leq 0.05$

Regarding age, according to the two instruments used it is possible to observe that subjective well-being average are significantly lower for the older children. The children who do not live in the capital of the state scored higher in well-being in the PWI-SC than the ones from the capital city. There was no significant difference in wellbeing for children attending public or private schools. Regarding gender, it is possible to observe that, in the SLSS, boys scored significantly higher in well-being.

There is a significant interaction between city and the type of school concerning SLSS. The children who scored higher in well-being are those who live in country cities and study in public schools $(M=0.08, S D=1.02)$ than the ones who live in the capital city and study in private schools $(M=0.09, S D=0.93)$. This interaction can be observed in Fig. 1.

Table 7 Analysis of variance and mean: Subjective well-being

\begin{tabular}{|c|c|c|c|c|c|c|c|c|}
\hline \multirow{2}{*}{$\begin{array}{l}\begin{array}{l}\text { Independent } \\
\text { variables }\end{array} \\
\text { Age }\end{array}$} & \multirow{2}{*}{$\begin{array}{l}\text { Dependent } \\
\text { variables }\end{array}$} & \multicolumn{2}{|c|}{ Factor means (SD) } & \multirow{2}{*}{$\begin{array}{l}\text { Sum of } \\
\text { squares }\end{array}$} & \multirow{2}{*}{$d f$} & \multirow[t]{2}{*}{$d f$ error } & \multirow[t]{2}{*}{$F$} & \multirow[t]{2}{*}{ Sig. } \\
\hline & & 10 years & 12 years & & & & & \\
\hline & PWI-SC & $0.15(0.89)$ & $-0.17(1.08)$ & 45.459 & 1 & 45.459 & 47.196 & $0.001 * *$ \\
\hline & SLSS & $0.16(0.92)$ & $-0.20(1.05)$ & 51.970 & 1 & 51.970 & 54.582 & $0.001 * *$ \\
\hline \multirow[t]{3}{*}{ City } & & Capital & Country Town & & & & & \\
\hline & PWI-SC & $-0.04(1.03)$ & $0.08(0.93)$ & 6.762 & 1 & 6.762 & 7.020 & $0.008 * *$ \\
\hline & SLSS & $-0.01(0.99)$ & $0.03(0.99)$ & 0.836 & 1 & 0.836 & 0.878 & 0.349 \\
\hline \multirow[t]{3}{*}{ Type of school } & & Public & Private & & & & & \\
\hline & PWI-SC & $-0.02(1.06)$ & $0.06(0.89)$ & 2.766 & 1 & 2.766 & 2.872 & 0.090 \\
\hline & SLSS & $-0.01(1.03)$ & $0.03(0.95)$ & 0.692 & 1 & 0.692 & 0.727 & 0.394 \\
\hline \multirow[t]{3}{*}{ Gender } & & Boys & Girls & & & & & \\
\hline & PWI-SC & $0.02(0.97)$ & $0.01(1.01)$ & 0.857 & 1 & 0.857 & 0.890 & 0.346 \\
\hline & SLSS & $0.08(0.95)$ & $-0.05(1.02)$ & 13.678 & 1 & 13.678 & 14.365 & $0.001 * *$ \\
\hline \multirow[t]{2}{*}{ City * Type of school } & PWI-SC & $\mathrm{a}$ & & 0.502 & 1 & 0.502 & 0.521 & 0.471 \\
\hline & SLSS & & & 5.667 & 1 & 5.667 & 5.952 & $0.015^{*}$ \\
\hline
\end{tabular}

\footnotetext{
${ }^{\text {a }}$ Means are described throughout the text

$* p \leq 0.05 ; * * p \leq 0.01$
} 


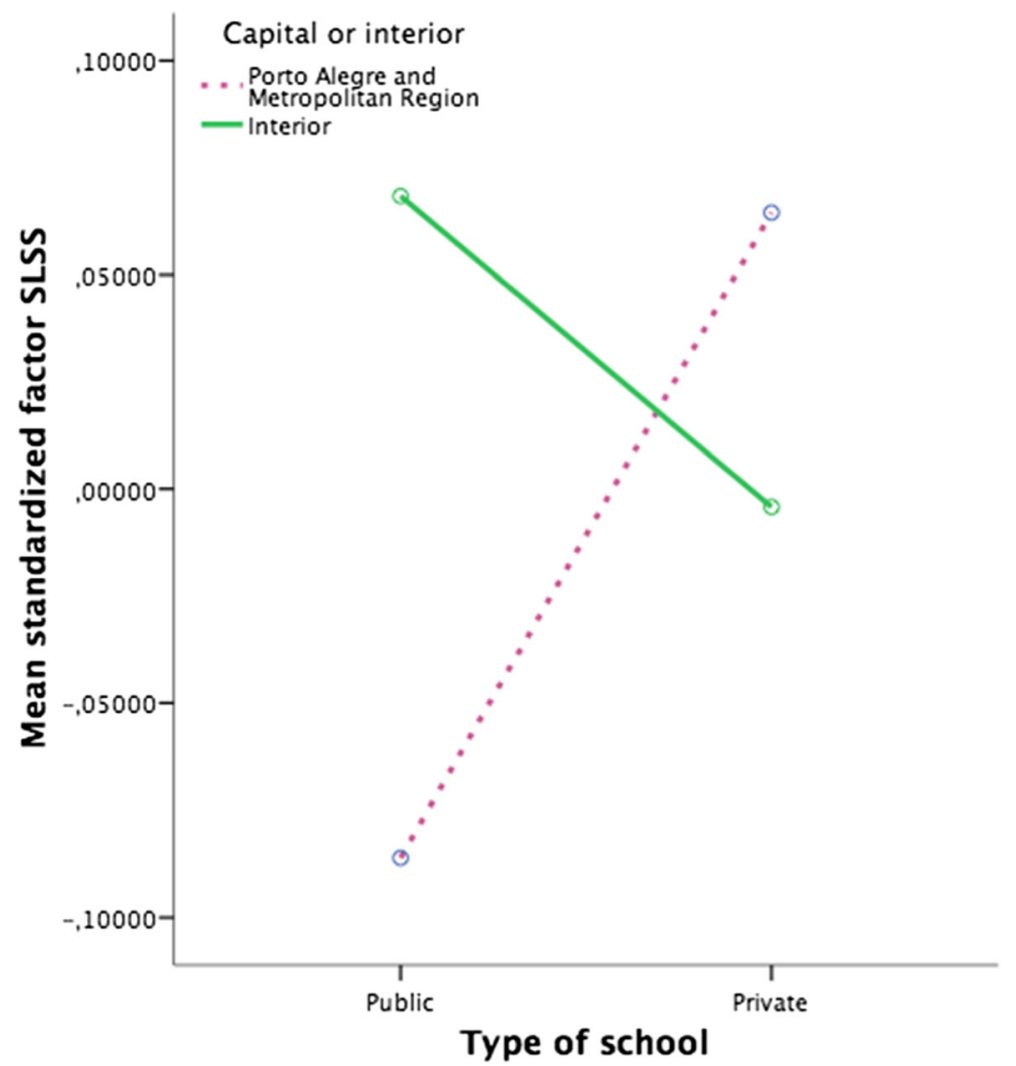

Fig. 1 Interaction graph between City and type of School

The results highlight that the public schools in the country cities presented a high index of well-being, as opposed to the capital city. In terms of city and type of school, country city children show less variation in their well-being levels than the ones from the capital.

\section{Discussion}

This study aimed to associate the satisfaction of children regarding interpersonal relationships in their main interaction contexts (family, friends and school) and their satisfaction with their subjective well-being, considering age, gender, type of school (public or private) and housing context (whether capital or not). There were significant differences in children's satisfaction concerning their interpersonal relationships with regard to gender, type of school and housing context. There was no significant difference related to satisfaction with interpersonal relationship as a function of age.

The girls were more satisfied in their relationships than the boys regarding friends and school. There were no significant differences in satisfaction with family relationships, opposing literature that points out boys' satisfaction with their parents' relationship (Bradshaw et al. 2011). Girls are more satisfied with their friendships contradicting previous studies showing lower satisfaction due to being more easily hurt (MacEvoy 
and Asher 2012). Girls are also more satisfied with their relationships at school, as was also observed by Casas et al. (2012).

As for the type of school, children from the private ones presented higher levels of satisfaction with their family relationships and at school, while public school children were more satisfied with their relationships with friends. The public school students' families generally have a lower income, which may require their parents more working time and less time with them, contributing to children's lower satisfaction with family relationships (McAuley et al. 2012). The Brazilian public schools environment is more influenced by political and governmental changes than the private one. In addition, students are often relocated to new groups at the beginning of the school year, even if they do not change schools. These changes interfere in school relationship and students' well-being, and may contribute to reduce the satisfaction of public school students with their relationships in the school environment (Montserrat et al. 2015). Many public school teachers are forced to work with the availability of few resources, some work in different schools and are unable to know each child individually, being then difficult to establish a close and trustworthy relationship something which interferes with school well-being (Cava 2011; Lima 2012). As for friends, children in private schools generally have less free time to spend with them, much of their time out of school is taken up by structured activities, being them as busy as their parents are. Public school children generally have more free time, being able to choose what to do and having more free time to play with their friends (McAuley et al. 2012).

When we consider the context of housing, we found out that children living in country cities have a higher level of satisfaction with family relationships, which can be understood as influence of the city's characteristics in their relationships. Parents spend less time going to their workplace, feel less tired, can share more time with their children, and some families even eat lunch together every day. This is more difficult to have in larger cities due to traffic and distance between and work places. Living with the extended family is also more common in smaller cities, increasing children relations' network (Tsai and Dzorgbo 2012). The country towns, because they are safer, even allow children to play outdoors more freely, encouraging families' interaction during leisure time (Lee and Yoo 2015).

Regarding well-being, there were significant differences in the variables city (place of residence), gender and age, and in the interaction between the variables city and type of school. Regarding housing context, there was a divergence between the instruments to assess well-being: no significant differences were observed between the well-being of children from the country towns and the ones from the capital in the SLSS. However, in the PWI, children living in the country towns had significantly higher well-being average scores than those in the capital, according to the literature (Vieira et al. 2015). One can consider the conditions and quality of life provided by country cities, such as greater safety and more freedom, allowing children to play outdoors and the appropriation of the territory where they live as well. In the capital, due to the higher rates of violence and insecurity, most children spend much of their time indoors or in other enclosed places.

There were no significant differences in the well-being of the participants in relation to the type of school. We believe this is a positive result, given that the type of school the children attend is related to socioeconomic factors, and the children from public schools are resilient in maintaining high levels of well-being, 
despite the difficulties and setbacks inherent to public education in Brazil. The gender reveals significant differences in well-being, with boys having higher levels, which also appears in Lee and Yoo (2015) and Casas et al. (2012). We can think of development as a possible explanation, as since girls tend to mature earlier, feeling safer to worry (Bretas et al. 2011). The social pressure to reach a certain standard of beauty is also stronger on girls and can influence satisfaction with their own body and their well-being (Guizzo 2012). In addition, there is a high level of gender-based violence in Brazil, with girls being exposed and vulnerable since early childhood (Waiselfisz 2015). These factors, related to development and culture influence girls' well-being more than boys'.

Regarding age, children under 12 have lower average well-being scores compared to 10-year-olds. This result corroborates findings from previous studies. Tomyn and Cummins (2011) found out a decrease in subjective well-being of Australian adolescents with age increase, from 12 to 16 years old. According to Casas et al. (2012), this result can be understood as the normal development of adolescents in the context of many societies. The authors point out that subjective well-being has been studied with the same instruments only for two decades, so these results were not obtained earlier. In Bedin and Sarriera (2015) and Vieira et al. (2015), the results also showed that the average well-being scores of adolescents decrease with age.

We intended to study children's interpersonal relationships with their families, friends and school because we consider these relationships have a great influence on the children's positive and negative affective experience. As the subjective well-being consists of a cognitive evaluation of one's own life and the positive and negative affections, both concepts are related. Our study points out that this relationship is positive. In an earlier study (Santos and Galli 2017), it was shown that interpersonal relationships are responsible for $40 \%$ of well-being, standing out in relation to other domains. However, the concept of well-being is broader, so that we decided to verify the influence of age, gender, school context and housing, which could affect other domains, such as material things, neighbourhood, health, use of time and personal satisfaction (Lee and Yoo 2015).

According to the results in this study, we can observe that interpersonal relationships and well-being are influenced by psychosocial variables, such as gender, type of school and context of children's housing. The study contributes to the area by showing both can be influenced by the same independent variables, and clarifies that the satisfaction with relationships is linked to the characteristics of the context they are established in and also the people involved, highlighted as possible foci of interventions to improve the quality of these relationships.

Children from a single Brazilian state participated in the study, which may be limiting because it prevents the generalization of results. Further studies involving representative samples from each state will lead to a better understanding regarding the influence of the research variables on satisfaction concerning children's relationships and their well-being. The study design can also be limiting because it is cross-sectional with a single moment data collection. Future studies accompanying children over a period of time could clarify aspects such as causality and verify if the participants' response patterns remain over time, in addition to encompassing a wider age range. 


\section{References}

Bedin, L. M., \& Sarriera, J. C. (2014). Dyadic analysis of parent-children subjective well-being. Child Indicators Research, 7(3), 613-631. https://doi.org/10.1007/s12187-014-9235-9.

Bedin, L. M., \& Sarriera, J. C. (2015). A comparative study of the subjective well-being of parents and adolescents considering gender, age and social class. Social Indicators Research, 120(1), 79-95. https://doi.org/10.1007/s11205-014-0589-7.

Ben-Zur, H. (2003). Happy adolescents: The link between subjective well-being, internal resources, and parental factors. Journal of Youth and Adolescence, 32(2), 67-79.

Borgers, N., Leeuw, E., \& Hox, J. (2000). Children as respondents in survey research: Cognitive development and response quality. Bulletin de Méthodologie Sociologique, 66, 60-75.

Bradshaw, J., Keung, A., Rees, G., \& Goswami, H. (2011). Children's subjective well-being: International comparative perspectives. Children and Youth Services Review, 33, 548-556.

Bretas, J. R. S., Ohara, C. V. S., Jardim, D. P., Junior, W. A., \& Oliveira, J. R. (2011). Aspectos da sexualidade na adolescência. Ciência \& Saúde Coletiva, 16(7), 3221-3228. https://doi.org/10.1590/S141381232011000800021.

Casas, F. (2011). Subjective social indicators and child and adolescent well-being. Child Indicators Research, 4(4), 555-575. https://doi.org/10.1007/s12187-010-9093-z.

Casas, F., Coenders, G., Gonzàlez, M., Malo, S., Bertran, I., \& Figuer, C. (2012). Testing the relationship between parents' and their children's subjective well-being. Journal of Happiness Studies, 13(6), 10311051. https://doi.org/10.1007/s10902-011-9305-3.

Casas, F., Bello, A., González, M., \& Aligué, M. (2013). Children's subjective well-being measured using a composite index: What impacts Spanish first-year secondary education students' subjective well-being? Child Indicators Research, 6(3), 433-460. https://doi.org/10.1007/s12187-013-9182-x.

Cava, M. J. (2011). Familia, profesorado e iguales: claves para el apoyo a las víctimas de acoso escolar. Psychosocial Intervention, 20(2), 183-192. https://doi.org/10.5093/in2011v20n2a6.

Chaplin, L. N. (2009). Please may I have a bike? Better yet, may I have a hug? An examination of children's and adolescents happiness. Journal of Happiness Studies, 10(5), 541-562. https://doi.org/10.1007 /s10902-008-9108-3.

Cummins, R. A., \& Lau, A. L. D. (2005). Personal wellbeing index - School children. 3rd. Edition. Australian Centre on Quality of Life, School of Psychology, Deakin University, Melbourne.

Diener, E. (2012). New findings and future directions for subjective well-being research. American Psychologist, 67(8), 590-597. https://doi.org/10.1037/a0029541.

Diener, E., Suh, E. M., Lucas, R. E., \& Smith, H. L. (1999). Subjective well-being: Three decades of progress. Psychological Bulletin, 125(2), 276-302. https://doi.org/10.1037/0033-2909.125.2.276.

Fattore, T., Mason, J., \& Watson, E. (2009). When children are asked about their well-being: Towards a framework for guiding policy. Child Indicators Research, 2(1), 57-77. https://doi.org/10.1007/s12187008-9025-3.

Fletcher, A. C., Blair, B. L., Troutman, D. R., \& Madison, K. J. (2013). Identifying children's friendships across diverse contexts: Maternal and child perspectives. Journal of Social and Personal Relationships, 30(7), 858-880. https://doi.org/10.1177/0265407512472474.

Flook, L. (2011). Gender differences in adolescent's daily interpersonal events and well-being. Child Development, 82(2), 454-461. https://doi.org/10.1111/j.1467-8624.2010.01521.x.

Gilman, R., \& Huebner, S. (2003). A review of life satisfaction research with children and adolescents. School Psychology Quarterly, 18(2), 192-205.

Glick, G. C., Rose, A. J., Swenson, L. P., \& Waller, E. M. (2013). Associations of mothers' friendships quality with adolescents' friendship quality and emotional adjustment. Journal of Research on Adolescence, 23(4), 730-743. https://doi.org/10.1111/jora.12021.

Goswami, H. (2012). Social relationships and children's subjective well-being. Social Indicators Research, 107(3), 575-588.

Graham, J. R., \& Shier, M. L. (2010). Social work practitioners and subjective well-being: Personal factors that contribute to high levels of subjective well-being. International Social Work, 53(6), 757-772.

Guizzo, B. S. (2012). Gender, body, and beautification: Girls learning femininity in Brazil. Revista Ártemis, 13(2), 110-118.

Haynie, D. L., Doogan, N. J., \& Soller, B. (2014). Gender, friendship networks and delinquency: A dynamic network approach. Criminology, 52(4), 688-722. https://doi.org/10.1111/1745-9125.12052. 
Horfve-Sabel, M. A. (2014). Learning, interaction and relationships as components of student well-being: Differences between classes from students and teacher perspective. Social Indicators Research, 119, 1535-1555. https://doi.org/10.1007/s11205-013-0557-7.

Huebner, E. S. (1991). Initial development of the students' life satisfaction scale. School Psychology International, 12, 231-240. https://doi.org/10.1177/0143034391123010.

Huebner, E. S., \& Alderman, G. L. (1993). Convergent and discriminant validation of a children's life satisfaction scale: Its relationship to self- and teacher-reported psychological problems and school functioning. Social Indicators Research, 30, 71-82. https://doi.org/10.1007/BF01080333.

ISCWeB - International Survey of Children's Well-Being. (2013). Components of the questionnaire. Retrieved from: http:/www.isciweb.org/_Uploads/dbsAttachedFiles/ISCWeB_Parts-of-thequestionnaire(1).pdf

John-Akinola, Y. O., \& Nic-Gabhainn, S. (2014). Children's participation in school: A cross-sectional study of the relationship between school environments, participation and health and well-being outcomes. $B M C$ Public Health, 14, 964. https://doi.org/10.1186/1471-2458-14-964.

Kelly, J. (1992). Psicología comunitária: el enfoque ecológico contextualista. Argentina, Buenos Aires: Centro Editor de América Latina.

Lee, B. J. (2014). Mapping domains and indicators of children's well-being. In A. Ben-Arieh, F. Casas, I. Frones \& J.E. Korbin, Handbook of child well-being, pp. 2797-2805.

Lee, B. J., \& Yoo, M. S. (2015). Family, school and community correlates of children's subjective well-being: An international comparative study. Child Indicators Research, 8(1), 151-175. https://doi.org/10.1007 /s12187-014-9285-z.

Li, T., \& Fung, H. H. (2014). How avoidant attachment influences subjective well-being: An investigation about the age and gender differences. Aging and Mental Health, 18(1), 4-10. https://doi.org/10.1080 /13607863.2013.775639.

Lima, V. M. M. (2012). A complexidade da docência nos anos iniciais na escola pública. Nuances: Estudos sobre Educação, 22(23), 148-166.

MacEvoy, J. P., \& Asher, S. R. (2012). When friends disappoint: Boys' and girls' responses to transgressions of friendship expectations. Child Development, 83(1), 104-119. https://doi.org/10.1111/j.14678624.2011.01685.x.

Malo, S., Navarro, D., \& Casas, F. (2012). El uso de los medios audiovisuales en la adolescencia y su relación con el bienestar subjetivo: análisis cualitativo desde la perspectiva intergeneracional y de género. Athenea Digital, 12(3), 27-49.

McAuley, C., McKeown, C., \& Merriman, B. (2012). Spending time with family and friends: children's views on relationships and shared activities. Child Indicators Research, 5(3), 449-467. https://doi.org/10.1007 /s12187-012-9158-2.

Miller, S. R., Tserakhava, V., \& Miller, C. J. (2011). My child is shy and has no friends: What does parenting have to do with it? Journal of Youth and Adolescence, 40(4), 442-452. https://doi.org/10.1007/s10964010-9550-5.

Montserrat, C., Dinisman, T., Baltatescu, S., Grigoras, B. A., \& Casas, F. (2015). The effect of critical changes and gender on adolescents' subjective well-being: Comparisons across 8 countries. Child Indicators Research, 8(1), 111-131. https://doi.org/10.1007/s12187-014-9288-9.

Rafnsson, S. B., Shankar, A., \& Steptoe, A. (2015). Longitudinal influences of social network characteristics on subjective well-being of older adults: Findings from the ELSA study. Journal of Aging and Health, 27(5), 919-934.

Santos, B. R. \& Galli, F. (2017). Subjective well-being intervention: focus on children interpersonal relationships through social and emotional learning. In J. C. Sarriera \& L. M. Bedin (eds), Psychosocial Wellbeing of Children and Adolescents in Latin America (pp. 291-317), Children's Well-being: Indicators and Research 16. doi:https://doi.org/10.1007/978-3-319-55601-7_14.

Sarriera, J. C. (2010). O paradigma ecológico na psicologia comunitária: do contexto à complexidade. Em J. C. Sarriera \& H. T. Saforcada (Orgs), Introdução à Psicologia Comunitária (pp. 27-48). Porto Alegre: Sulina.

Sarriera, J. C., Schütz, F. F., Galli, F., Bedin, L. M., Strelhow, M. R. W., \& Calza, T. Z. (2014). Informe de pesquisa: bem-estar na infância e fatores psicossociais associados. Brazil, Porto Alegre: editora Concórdia.

Seligman, M. E., \& Csikszentmihalyi, M. (2000). Positive psychology: An introduction. American Psychologist, 55(1), 5-14. https://doi.org/10.1037/0003-066x.55.1.5.

Seligson, J. L., Huebner, E. S., \& Valois, R. F. (2003). Preliminary validation of the brief multidimensional student's life satisfaction scale. Social Indicators Research, 61, 121-145. 
Shin, H., \& Ryan, A. M. (2014). Friendship networks and achievement goals: An examination of selection and influence processes and variations by gender. Journal of Youth and Adolescence, 43(9), 1453-1464. https://doi.org/10.1007/s10964-014-0132-9.

Sortheix, F. M., \& Lonnqvist, J. E. (2015). Person-group value congruence and subjective well-being in students from Argentina, Bulgaria and inland: the role of interpersonal relations. Journal of Community \& Applied Social Psychology, 25, 34-48. https://doi.org/10.1002/casp.2193.

Souza, L. K., Silveira, D. C., \& Rocha, M. A. (2013). Lazer e amizade na infância: implicações para saúde, educação e desenvolvimento infantil. Psicologia da Educação, 36, 83-92.

Strelhow, M. R. W., Calza, T. Z., Schütz, F., \& Sarriera, J. C. (2013). Children's overall life satisfaction: Importance of family, school and relationships with others. In 4th International Society for Child Indicators (ISCI) international conference. South Korea: Seoul National University, Seoul.

Tomyn, A. J., \& Cummins, R. A. (2011). The subjective wellbeing of high-school students: Validating the personal wellbeing index -school children. Social Indicators Research, 101(3), 405-418. https://doi. org/10.1007/s11205-010-9668-6.

Troop-Gordon, W., \& Kopp, J. (2011). Teacher-child relationship quality and children's peer victimization and aggressive behavior in late childhood. Social Development, 20(3), 536-561. https://doi.org/10.1111 /j.1467-9507.2011.00604.x.

Tsai, M. C., \& Dzorgbo, D. B. S. (2012). Familial reciprocity and subjective well-being in Ghana. Journal of Marriage and Family, 74(1), 215-228. https://oi.org/10.1111/j.1241-3737.2011.00874x.

Vieira, T. P. F., Alves, N. J. C. R. C., Dias, C. S. L., \& Fonseca, A. M. L. F. M. (2015). Assimetrias regionais. Que diferenças nos estilos de vida e na satisfação com a vida dos adolescentes? Um estudo realizado em alunos do $3^{\circ}$ ciclo do Ensino Básico de Portugal. Ciência \& Saúde Coletiva, 20(1), 17-28. https://doi. org/10.1590/1413-81232014201.18252013.

Waiselfisz, J. J. (2015). Mapa da violência 2015- Homicídios de mulheres no Brasil. Disponível em www. mapadaviolencia.org.br

Wilmes, J., \& Andresen, S. (2015). What does "good childhood" in a comparative perspective mean? An explorative comparison of child well-being in Nepal and Germany. Child Indicators Research, 8(1), 3347. https://doi.org/10.1007/s12187-014-9292-0.

Yucel, D., \& Yuan, A. V. (2015). Do siblings matter? The effect of siblings on socio-emotional development and educational aspirations among early adolescents. Child Indicators Research, 8(3), 671-697. https://doi.org/10.1007/s12187-014-9268-0. 